\title{
Kinetics of Expression of the Gene Encoding the 65-Kilodalton DNA-Binding Protein of Herpes Simplex Virus Type 1
}

\author{
LEO D. GOODRICH, ${ }^{1}$ FRAZER J. RIXON,$^{2}$ AND DEBORAH S. PARRIS ${ }^{1.3 *}$ \\ Program in Molecular, Cellular, and Developmental Biology ${ }^{1}$ and Department of Medical Microbiology and Immunology \\ and Comprehensive Cancer Center, ${ }^{3}$ The Ohio State University, Columbus, Ohio 43210, and Medical Research Council \\ Virology Unit, Institute of Virology, Glasgow GII 5JR, Scotland ${ }^{2}$
}

Received 14 June 1988/Accepted 3 September 1988

\begin{abstract}
The 65-kilodalton DNA-binding protein $\left(65 \mathrm{~K}_{\mathrm{DBP}}\right)$ of herpes simplex virus type 1 , encoded by gene UL42, is required for herpes simplex virus origin-dependent DNA replication (C. A. Wu, N. J. Nelson, D. J. McGeoch, and M. D. Challberg, J. Virol. 62:435-443, 1988). We found by indirect immunofluorescence with monoclonal antibody to $65 \mathrm{~K}_{\mathrm{DBP}}$ that the protein was first detectable at $3 \mathrm{~h}$ postinfection. It localized first to the inner periphery of the nucleus, but accumulated in large globular compartments within the nucleus by $6 \mathrm{~h}$ postinfection in a pattern similar to that displayed by the major DNA-binding protein ICP8. Immune electron microscopy revealed that $65 \mathrm{~K}_{\mathrm{DBP}}$ was associated with the marginated heterochromatin at the early times, but migrated further into the nucleus at late times when the only discernible areas devoid of $65 \mathrm{~K}_{\mathrm{DBP}}$ were the nucleoli and heterochromatin. The $65 \mathrm{~K}_{\mathrm{DBP}}$ gene is a member of the $\beta$ kinetic class as determined by the ability of the mRNA to be expressed at significant levels even in the absence of viral DNA synthesis. Furthermore, in the presence or absence of the DNA polymerase inhibitor phosphonoacetic acid, the patterns of accumulation of protein as well as mRNA were virtually indistinguishable from those displayed by the model $\beta$ genes encoding ICP8 and thymidine kinase. Nuclear run-on experiments demonstrated that maximum rates of $\mathbf{6 5 K}_{\mathrm{DBP}}$ gene transcription occurred prior to the maximum rate of progeny viral DNA synthesis and confirmed that the expression of the $65 \mathrm{~K}_{\mathrm{DBP}}$ gene is regulated at the level of transcriptional initiation.
\end{abstract}

Herpes simplex virus type 1 (HSV-1) is predicted to encode 70 proteins, on the basis of the sequence of the entire genome (22). Of these, 15 to 20 proteins have been classified as DNA-binding proteins $(2,28)$. One such protein is the 65-kilodalton DNA-binding protein $\left(65 \mathrm{~K}_{\mathrm{DBP}}\right)$ which is present in nuclear extracts of infected cells and elutes at high salt concentrations from double-stranded-DNA-cellulose columns (21). Recently, it was demonstrated that $65 \mathrm{~K}_{\mathrm{DBP}}$ is capable of binding to DNA in the absence of other proteins (9).

The gene encoding $65 \mathrm{~K}_{\mathrm{DBP}}$ maps in the HindIII L fragment and corresponds to UL42 (26). Several pieces of evidence indicate that $65 \mathrm{~K}_{\mathrm{DBP}}$ is involved in DNA replication: (i) UL42 is one of only seven HSV-1 genes required for the replication of plasmids containing an $\mathrm{HSV}$ origin of replication (44); (ii) a temperature-sensitive mutant with a lesion which maps to coordinates occupied by UL42 does not synthesize viral DNA at the nonpermissive temperature (20); and (iii) $65 \mathrm{~K}_{\mathrm{DBP}}$ is closely associated with the viral DNA polymerase $(\mathrm{Pol})$, suggesting that it is a component of replication complexes $(9,42)$.

In an effort to begin to elucidate the role of $65 \mathrm{~K}_{\mathrm{DBP}}$ in viral DNA replication, we have examined the kinetics of synthesis of the mRNA and protein encoded by the gene and the relationship of these kinetics to viral DNA synthesis. Genes encoded by HSV-1 are coordinately regulated and sequentially expressed in the viral replicative cycle $(13,14)$, and the way in which the expression of a gene is regulated may reflect its role in viral replication. For example, many HSV proteins directly involved in viral DNA synthesis, e.g., Pol and the major DNA-binding protein, $\operatorname{ICP} 8(4,15,30,43)$, are classified as early or $\beta$ genes in that they are expressed prior to viral DNA synthesis and their levels of expression are

\footnotetext{
* Corresponding author.
}

relatively unaffected by DNA synthesis inhibitors $(12,13$, $32,37)$. Late or $\gamma$ genes are not expressed in the absence of viral DNA synthesis, and the products of such genes are typically structural components of the virion $(13,16,27)$.

In an early report, Frink et al. (7) demonstrated that a transcript which mapped to a region on the HSV-1 genome now known to encode the $65 \mathrm{~K}_{\mathrm{DBP}}$ was expressed in the presence of the viral DNA synthesis inhibitor adenosine arabinoside. It was, therefore, classified as an early or $\beta$ transcript. To characterize more thoroughly the kinetics with which the $65 \mathrm{~K}_{\mathrm{DBP}}$ gene is expressed, we have examined not only the accumulation of $65 \mathrm{~K}_{\mathrm{DBP}}$ mRNA and protein, as compared to other well-characterized early and late viral gene products, but also the rate of initiation of transcription from the gene in the presence or absence of concomitant viral DNA synthesis. We present evidence that synthesis of $65 \mathrm{~K}_{\mathrm{DBP}}$ begins prior to viral DNA synthesis, but the protein continues to accumulate even late after infection. Using indirect immunofluorescence with monoclonal antibodies (MAbs) to $65 \mathrm{~K}_{\mathrm{DBP}}$ and ICP8, we have demonstrated that the kinetics of intranuclear localization of the $65 \mathrm{~K}_{\mathrm{DBP}}$ are the same as those of the $\beta$ gene product, ICP8. In addition, relatively high steady-state levels of $65 \mathrm{~K}_{\mathrm{DBP}}$ mRNA were achieved even in the presence of the DNA synthesis inhibitor phosphonoacetic acid (PAA), similar to the pattern observed for other $\beta$ genes. Taken together, these data clearly indicate that the gene encoding $65 \mathrm{~K}_{\mathrm{DBP}}$ is a member of the $\beta$ class of HSV-1 genes. We also present data which demonstrate that control of $65 \mathrm{~K}_{\mathrm{DBP}}$ gene expression is at the level of transcriptional initiation.

\section{MATERIALS AND METHODS}

Growth of cells and virus. African green monkey kidney (Vero) cells were cultivated in Dulbecco modified minimum essential medium (Flow Laboratories, McLean, Va.) supple- 
mented with $5 \%$ newborn calf serum and $2.5 \%$ fetal bovine serum, and baby hamster kidney fibroblast (BHK) cells were grown in similar medium supplemented with $7.5 \%$ fetal bovine serum. Stocks of HSV-1 strain KOS (38) and strain $17 \operatorname{syn}^{+}$(3) were obtained by low-multiplicity passage of plaque-purified isolates in Vero cells as previously described $(3,25)$.

Plasmid and antibody probes. Plasmid probes were constructed by standard methods (18). The sequence of the HindIII L fragment of HSV-1 strain 17 was kindly provided by Duncan McGeoch $(22,23)$. The plasmid pGX80, containing the HindIII L fragment, was produced by B. Matz and used to obtain subclones specific for $65 \mathrm{~K}_{\mathrm{DBP}}$ and glycoprotein C (gC). Plasmid pLPS19A contained a 738-base-pair PstI fragment located entirely within the $65 \mathrm{~K}_{\mathrm{DBP}}$ open reading frame (23), cloned into the PstI site of the multifunctional cloning vector pTZ19U (United States Biochemical Corp., Cleveland, Ohio). Plasmid pgC-EX was constructed by cloning the 918-base-pair EcoRI-to-XbaI fragment located within the open reading frame encoding $\mathrm{gC}(8)$ into the multiple cloning site of pTZ18U. Plasmid pTZTK3 was derived from the plasmid pTK1 (35) and contains the 503base-pair BglII-to-SstI fragment, which overlaps the $5^{\prime}$ end of the thymidine kinase $(t k)$ transcript, cloned into pTZ18U.

MAb 6898 has been described previously (26) and was used to specifically detect $65 \mathrm{~K}_{\text {DBP. }}$ MAb $39 \mathrm{~S}$, which recognizes the HSV-1 major DNA-binding protein ICP8 (36), was kindly provided by Martin Zweig.

Immunofluorescence. Vero cells were seeded onto glass tissue culture chamber slides (Miles Laboratories, Naperville, Ill.) to attain a density of $3 \times 10^{5}$ cells per $2-\mathrm{cm}^{2}$ chamber at the time of infection. Cells were mock-infected or infected with HSV-1 at a multiplicity of infection (m.o.i.) of $25 \mathrm{PFU} / \mathrm{cell}$, and the virus was allowed to adsorb for 30 min at $37^{\circ} \mathrm{C}$ before incubation at $34^{\circ} \mathrm{C}$. At the indicated times postinfection (p.i.), the cell monolayers were washed with phosphate-buffered saline (PBS) and fixed in $3.7 \%$ formaldehyde in PBS at ambient temperature for $30 \mathrm{~min}$. Cells were again washed in PBS and stored at $4^{\circ} \mathrm{C}$ in PBS until stained.

Fixed cells were permeabilized by immersion in $-20^{\circ} \mathrm{C}$ acetone for $2 \mathrm{~min}$, followed by a PBS wash. The appropriate dilution of antibody was added, and the cells were incubated at $37^{\circ} \mathrm{C}$ for $30 \mathrm{~min}$ in a moist chamber. Cells were washed three times prior to the addition of the fluorescein isothiocyanate-conjugated secondary antibody (Cappel Laboratories, West Chester, Pa.) as indicated. After $30 \mathrm{~min}$ at $37^{\circ} \mathrm{C}$, cells were again washed three times in PBS, and cover slips were applied over mounting medium $(90 \%$ glycerol, $10 \%$ PBS, $150 \mathrm{mM}$ propyl gallate [Eastman Kodak Co., Rochester, N.Y.]).

Stained slides were viewed with a Zeiss fluorescence microscope using a $40 \times$ Neofluar objective. Stained cells were detected using a filter set consisting of a 455- to 490-nm exciter filter, a beam splitter for $<510 \mathrm{~nm}$, and a barrier filter for $>520 \mathrm{~nm}$ light. Photographs were taken with a 2-min exposure time using Kodak Tri-X Pan film.

Preparation of samples for electron microscopy. BHK cells, infected with 10 PFU of HSV-1 strain 17 per cell, were harvested by scraping into PBS. Samples were pelleted into BEEM capsules (Agar AIDs Ltd., Stanstad, Essex, United Kingdom) and fixed for $1 \mathrm{~h}$ with $2.5 \%$ glutaraldehyde in PBS. Samples were dehydrated and infiltrated with Lowicryl K4M (TAAB Laboratories Ltd., Aldermaston, Berkshire, United Kingdom), using a low-temperature embedding procedure as described previously (6). Sections were cut and collected on uncoated nickel grids.
Immunolocalization. All procedures were carried out at room temperature. Grids containing sections were submerged briefly in PBS containing $0.05 \%$ Tween 20. This solution was also used for all antibody dilutions and for washing the sections after treatment with antibody. The sections were transferred into an appropriate dilution of antibody for $45 \mathrm{~min}$ and then jet washed and placed in a 1:50 dilution of $10-\mathrm{nm}$ gold-linked goat anti-mouse antibody $\left(\mathrm{GAM}_{10}\right)$ (Janssen Life Sciences, Leithton Buzzard, Lutton, United Kingdom). After a further 45 min they were jet washed, rinsed in distilled water, and dried. Contrast was enhanced by exposing sections to $\mathrm{OsO}_{4}$ vapor for $1 \mathrm{~h}$. Sections were examined using a Jeol $100 \mathrm{~S}$ electron microscope.

Immunodetection of proteins in cell extracts. Extracts of infected (m.o.i., 10 PFU/cell) and mock-infected cells were prepared by the addition of buffer containing $0.4 \mathrm{M} \mathrm{NaCl}, 20$ $\mathrm{mM}$ Tris hydrochloride (pH 8.0), $1 \mathrm{mM}$ 2-mercaptoethanol, $1 \mathrm{mM}$ disodium EDTA, and $1 \mathrm{mM}$ phenylmethylsulfonyl fluoride, followed by sonication. The extracts were centrifuged at $12,000 \times g$, and the supernatant was analyzed for protein content by immunoblotting. Samples were either applied to nitrocellulose (Schleicher \& Schuell, Keene, N. H.), using a manifold device, or were first subjected to sodium dodecyl sulfate (SDS)-polyacrylamide gel electrophoresis (17) and then transferred to nitrocellulose according to the procedure of Towbin et al. (41). Proteins reactive to antibody were detected using ${ }^{125}$ I-protein A (Amersham Corporation, Arlington Heights, Ill.) as previously described (9).

Northern (RNA) blot analysis. Cytoplasmic RNA was prepared from BHK cells infected with HSV-1 at an m.o.i. of $10 \mathrm{PFU} /$ cell as described by Preston (29), and poly(A)containing mRNA was selected by oligo(dT)-cellulose column chromatography (1). The mRNA was treated with glyoxal and dimethyl sulfoxide, electrophoresed through a $1.0 \%$ agarose gel with an RNA ladder as size markers (Bethesda Research Laboratories, Gaithersburg, Md.), and transferred to Nytran (Schleicher \& Schuell) essentially as described by Thomas (40). Blots were probed with ${ }^{32} \mathrm{P}$ labeled DNA prepared by nick translation of plasmids, using a kit (Bethesda Research Laboratories) according to the instructions of the manufacturer. Hybridization buffer contained $5 \times \mathrm{SSC}(1 \times \mathrm{SSC}$ is $0.15 \mathrm{M} \mathrm{NaCl}$ plus $0.015 \mathrm{M}$ sodium

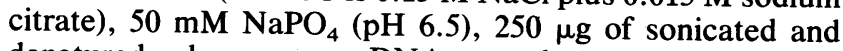
denatured salmon sperm DNA per ml, $1 \times$ Denhardt solution, $0.05 \%$ SDS, and $50 \%$ formamide. Blots were hybridized at $48^{\circ} \mathrm{C}$ for $24 \mathrm{~h}$, washed at $48^{\circ} \mathrm{C}$ in decreasing salt concentrations to $0.1 \times \mathrm{SSC}-0.1 \% \mathrm{SDS}$, and exposed to $\mathrm{X}$-ray film at $-85^{\circ} \mathrm{C}$ with intensifying screens. Blots which were reprobed with a different plasmid were first stripped with boiling water and hybridized as before. Multiple exposures of the resulting autoradiograms were scanned with an LKB (Piscataway, N.J.) Ultroscan XL Laser Densitometer equipped with a Gelscan XL program.

Nuclear run-on transcription assays. Nuclei were isolated and in vitro transcription reactions were performed as described by Groudine et al. (11), with a few modifications. Briefly, BHK cells mock-infected or infected with HSV-1 at an m.o.i. of $10 \mathrm{PFU} /$ cell were washed in PBS, collected by centrifugation, and suspended in buffer containing $20 \mathrm{mM}$

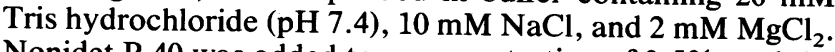
Nonidet P-40 was added to a concentration of $0.5 \%$, and the cells were placed on ice for $5 \mathrm{~min}$ to lyse the cytoplasmic membranes. Nuclei were collected by centrifugation for 2 min at $2,600 \times g$, washed in cold nuclear storage buffer ( 50 
$\mathrm{mM}$ Tris hydrochloride, $\mathrm{pH} 7.5,5 \mathrm{mM} \mathrm{MgCl}_{2}, 0.1 \mathrm{mM}$ EDTA, $40 \%$ glycerol), suspended in a small volume of nuclear storage buffer, and stored at $-85^{\circ} \mathrm{C}$.

Transcription reactions were performed using $1.6 \times 10^{7}$ nuclei in $50 \mu \mathrm{l}$ of storage buffer to which $50 \mu$ l of buffer containing $0.2 \mathrm{M}$ Tris hydrochloride ( $\mathrm{pH} 7.8), 100 \mathrm{mM} \mathrm{NaCl}$, $0.70 \mathrm{M}\left(\mathrm{NH}_{4}\right)_{2} \mathrm{SO}_{4}, 4 \mathrm{mM}$ EDTA, $8 \mathrm{mM} \mathrm{MnCl} 2,2 \mathrm{mM}$ each of ATP, GTP, and CTP, $2 \mathrm{mg}$ of heparin per $\mathrm{ml}$, and $0.1 \mathrm{mCi}$ of $\left[{ }^{32} \mathrm{P}\right]$ UTP was added. The reactions were incubated for 45 $\min$ at $32^{\circ} \mathrm{C}$ and stopped by the addition of $350 \mu \mathrm{l}$ of a solution containing $20 \mathrm{mM}$ Tris hydrochloride ( $\mathrm{pH} \mathrm{7.5),} 10$ $\mathrm{mM} \mathrm{CaCl} 2,25 \mu \mathrm{g}$ of DNase I (Bethesda Research Laboratories), $25 \mu \mathrm{g}$ of proteinase $\mathrm{K}$ (Boehringer Mannheim, Indianapolis, Ind.), and $10 \mu \mathrm{g}$ of Escherichia coli tRNA (Sigma Chemical Co., St. Louis, Mo.). Samples were incubated for an additional $30 \mathrm{~min}$ at $37^{\circ} \mathrm{C}$, followed by the addition of EDTA and SDS to final concentrations of $20 \mathrm{mM}$ and $1 \%$, respectively; the samples were then incubated at $37^{\circ} \mathrm{C}$ for 15 min. RNA was extracted once with phenol- $\mathrm{CHCl}_{3}$-isoamyl alcohol $(25: 24: 1)$, trichloroacetic acid was added to a final concentration of $10 \%$, and the samples were placed on ice for $15 \mathrm{~min}$. The precipitate was collected after centrifugation at $16,000 \times g$ and washed four times with ice-cold $5 \%$ trichloroacetic acid. The RNA pellets were dissolved in 10 $\mathrm{mM}$ Tris hydrochloride ( $\mathrm{pH}$ 7.5)-1 mM EDTA, followed by the addition of sodium acetate to $30 \mathrm{mM}$; they were then ethanol precipitated and suspended in sterile water.

Unlabeled plasmid pLPS19A DNA, representing sequences corresponding to the $65 \mathrm{~K}_{\mathrm{DBP}}$ open reading frame, was denatured in $\mathrm{NaOH}$, serially diluted, and applied to nitrocellulose in $6 \times \mathrm{SSC}$ by means of a manifold device. The baked filter was cut into strips and hybridized with the labeled RNA as described above for the Northern blots. Washed filters were exposed to $\mathrm{X}$-ray film at $-85^{\circ} \mathrm{C}$ using intensifying screens. Under these conditions, $5 \mu \mathrm{g}$ of cold DNA was sufficient to achieve an excess over labeled RNA (results not shown).

To determine the relative copy number of $65 \mathrm{~K}_{\mathrm{DBP}}$ gene sequences present in each nuclear preparation, a portion of each was removed prior to the addition of labeled UTP. DNA was extracted, treated with RNase A, and concentrated as previously described (39). The DNA was denatured, applied to nitrocellulose as described above, and hybridized to a ${ }^{32} \mathrm{P}$-labeled, nick-translated $\mathrm{pLPS19A}$ probe. Hybridization was performed at $65^{\circ} \mathrm{C}$ in $3 \times$ SSC $-0.5 \%$ SDS$2 \times$ Denhardt solution-2.5 $\mu \mathrm{g}$ of sonicated and denatured salmon sperm DNA per $\mathrm{ml}$ for $36 \mathrm{~h}$, and the blots were successively washed at $65^{\circ} \mathrm{C}$ in decreasing salt concentrations to $1 \times$ SSC $-0.1 \%$ SDS $-0.1 \%$ sodium pyrophosphate prior to autoradiography.

\section{RESULTS}

Localization of $65 \mathrm{~K}_{\mathrm{DBP}}$. To examine the intracellular distribution of $65 \mathrm{~K}_{\mathrm{DBP}}$ at various times p.i., we used MAb 6898 , specific for $65 \mathrm{~K}_{\mathrm{DBP}}(26)$, in indirect immunofluorescence tests. For comparison with a virus-encoded protein of known localization pattern and kinetic class, we analyzed parallel samples with MAb 39S, which recognizes the early polypeptide ICP8 (36). Little or no background fluorescence with either antibody was observed in mock-infected Vero cells (Fig. 1A and E) or at $2 \mathrm{~h}$ p.i. (results not shown) in cells infected with HSV-1 (KOS) at an input m.o.i. of $25 \mathrm{PFU} /$ cell. By $3 \mathrm{~h}$ p.i. $65 \mathrm{~K}_{\mathrm{DBP}}$ was detected in most of the cells examined, localizing exclusively in the nucleus. Although faint generalized nuclear fluorescence could be detected in many cells, pockets of higher concentrations of $65 \mathrm{~K}_{\mathrm{DBP}}$ accumulated at the inner periphery of the nuclear membrane at early times (Fig. 1B). At $6 \mathrm{~h}$ p.i. (Fig. 1C), the areas of intense staining increased in size, occupying a larger proportion of the nucleus, and by $12 \mathrm{~h}$ (Fig. 1D), $65 \mathrm{~K}_{\mathrm{DBP}}$ had accumulated in all areas of the nucleus with the exception of the nucleoli. However, in some cells (Fig. 1D), the periphery of the nucleus appeared poorly stained. ICP8 also began to accumulate at the inner periphery of the nucleus at $3 \mathrm{~h}$ p.i., and its pattern of accumulation was virtually indistinguishable from that of $65 \mathrm{~K}_{\mathrm{DBP}}$ through the times examined (Fig. 1, compare panels $B, C$, and D with F, G, and H). However, it should be noted that the pattern of fluorescence produced by MAb 39S was more granular in appearance at times of maximum accumulation than that produced by MAb 6898 (Fig. 1D and $\mathrm{H}$ ).

We also examined the pattern of $65 \mathrm{~K}_{\mathrm{DBP}}$ accumulation at a finer ultrastructural level by using colloidal gold to detect the protein in thin sections of cells. Figures $2 \mathrm{~A}$ and $\mathrm{B}$ show electron micrographs of a BHK cell fixed at $4 \mathrm{~h}$ p.i. and stained with MAb 6898 and GAM $_{10}$. Very few gold particles could be detected in the cytoplasm of the cell, and the majority of gold particles appeared to be associated with the heterochromatin, which is predominantly located at the inner periphery of the nucleus and around the outside of the nucleolus. At $12 \mathrm{~h}$ p.i., the gold particles were no longer localized to the marginated heterochromatin, but appeared throughout the nucleus. In fact, the only areas relatively devoid of $65 \mathrm{~K}_{\mathrm{DBP}}$ at late times postinfection were the disaggregated nucleoli and dense bodies (not shown) and the heterochromatin (Fig. 2C and D). Similar patterns were also seen using an antipeptide serum directed to $65 \mathrm{~K}_{\mathrm{DBP}}$ (results not shown). These results confirm the pattern of $65 \mathrm{~K}_{\mathrm{DBP}}$ localization detected by immunofluorescence. Immunodetection of the ICP8 by electron microscopy using MAb 39S was attempted, but failed because the MAb did not recognize its cognate epitope in the embedded material.

Kinetics of $65 K_{\mathrm{DBP}}$ accumulation. The localization studies demonstrated that $65 \mathrm{~K}_{\mathrm{DBP}}$ was expressed as early as ICP8, which has been classified as a $\beta$ polypeptide (13). Analysis of transcripts which were synthesized in the presence of adenosine arabinoside also indicated that the $65 \mathrm{~K}_{\mathrm{DBP}}$ transcripts accumulated as expected for a $\beta$ gene (7). However, to better determine the kinetic class to which $65 \mathrm{~K}_{\mathrm{DBP}}$ belongs, we examined a number of parameters indicative of gene expression, including protein and mRNA accumulation, and compared these in the same infected cells with the patterns of expression of well-characterized model $\beta$ and $\gamma$ genes.

We first quantified the amount of accumulated polypeptide at various times p.i. by immunoblot analysis. Reactivity of a $65 \mathrm{~K}$ polypeptide to MAb 6898 was again used. However, due to the lower sensitivity of the blotting procedure, we were only able to detect $65 \mathrm{~K}_{\mathrm{DBP}}$ by $5 \mathrm{~h}$ p.i. (Fig. 3). Large amounts of $65 \mathrm{~K}_{\mathrm{DBP}}$ could be detected at $8 \mathrm{~h}$ p.i., and the levels increased throughout the replicative cycle.

To determine the effect of DNA synthesis on the level of accumulation of $65 \mathrm{~K}_{\mathrm{DBP}}$ compared with that of ICP8, we infected cells in the presence and absence of PAA, a specific inhibitor of the HSV DNA polymerase $(19,24)$. Because MAb 39S readily detects only the native form of ICP8 and does not cross-react with other protein species (36; unpublished results), lysates of infected and mock-infected cells were applied directly to nitrocellulose and probed with either MAb 6898 or $39 \mathrm{~S}$ to detect $65 \mathrm{~K}_{\mathrm{DBP}}$ or ICP8, respectively. Like $65 \mathrm{~K}_{\mathrm{DBP}}$, a large amount of ICP8 was detected even late p.i. (Fig. 4). In the presence of $400 \mu \mathrm{g}$ of PAA per $\mathrm{ml}$, which 

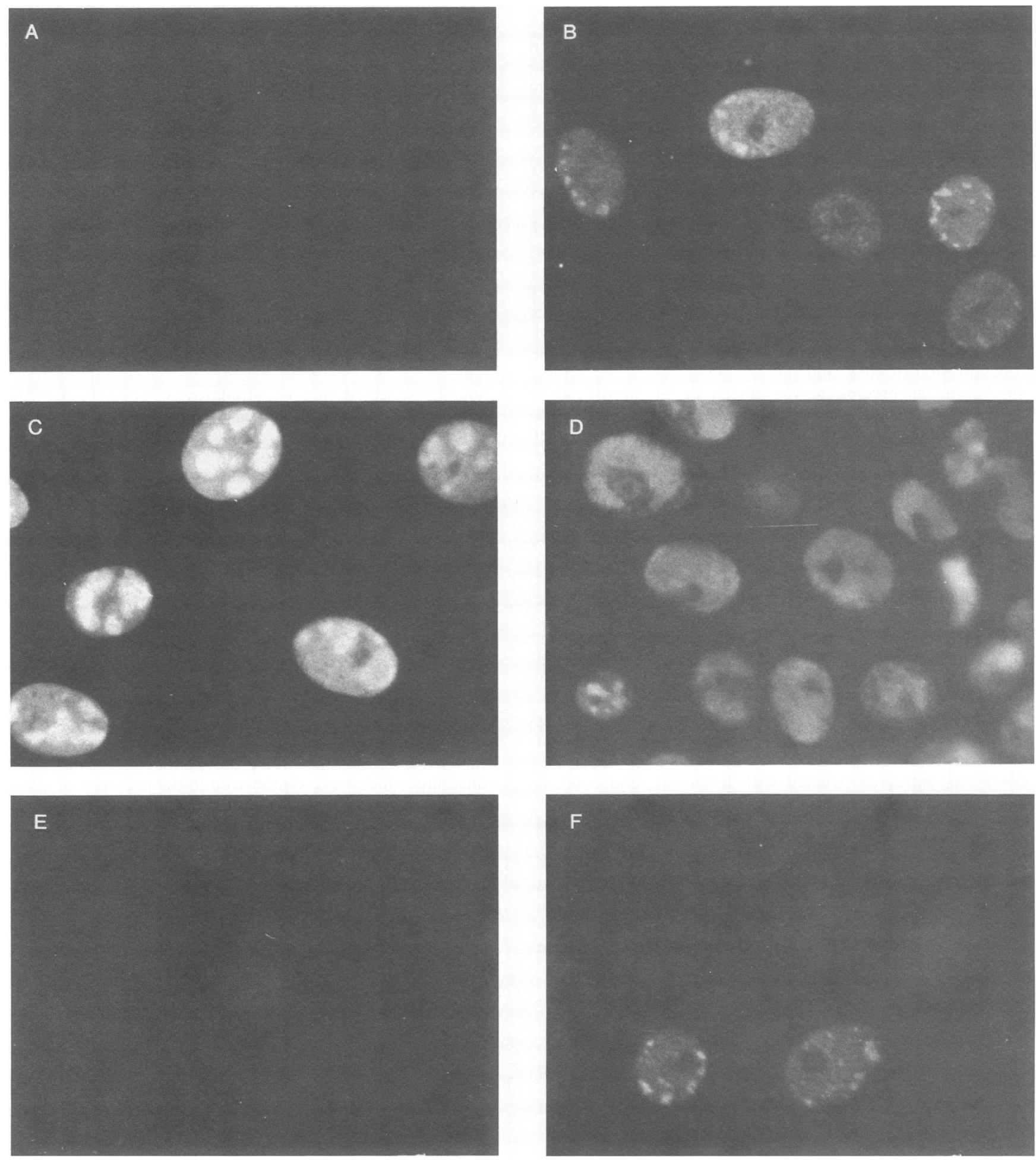

FIG. 1. Cellular localization of $65 \mathrm{~K}_{\mathrm{DBP}}$ and ICP8. Vero cells were mock-infected (A and E) or infected with HSV-1 (KOS) and incubated at $34^{\circ} \mathrm{C}$ for $3 \mathrm{~h}(\mathrm{~B}$ and $\mathrm{F}), 6 \mathrm{~h}(\mathrm{C}$ and $\mathrm{G})$, or $12 \mathrm{~h}(\mathrm{D}$ and $\mathrm{H})$. Cells were stained with either a 1/1,000 dilution of MAb 6898 (A through D) or a $1 / 100$ dilution of $39 \mathrm{~S}(\mathrm{E}$ through $\mathrm{H})$, followed by a $1 / 100$ or $1 / 50$ dilution of fluorescein isothiocyanate-conjugated goat anti-mouse immunoglobulin $\mathrm{G}$ to detect $65 \mathrm{~K}_{\mathrm{DBP}}$ or ICP8, respectively. 

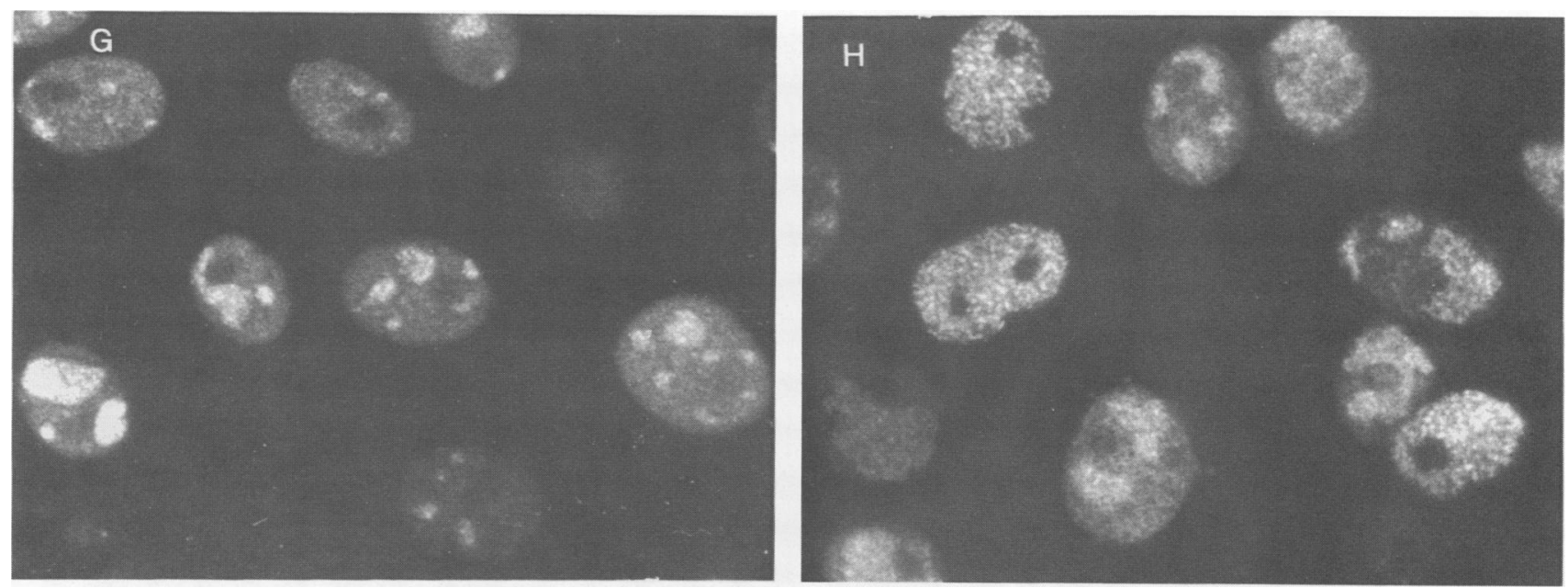

FIG. 1-Continued.

is sufficient to completely prevent viral DNA synthesis (10; unpublished results), the amount of both proteins was dramatically reduced compared with the levels detected in the absence of PAA (Fig. 4). The patterns of ICP8 and $65 \mathrm{~K}_{\mathrm{DBP}}$ accumulation in infected cells were indistinguishable from each other regardless of the ability of the virus to synthesize DNA.

Rate of accumulation of $65 \mathrm{~K}_{\mathrm{DBP}}$ mRNA. Because the increase in $65 \mathrm{~K}_{\mathrm{DBP}}$ accumulation may have reflected an increase in the amount of mRNA available for translation, increased efficiency of translation, or slow turnover of the $65 \mathrm{~K}_{\mathrm{DBP}}$, we analyzed the amount of $65 \mathrm{~K}_{\mathrm{DBP}} \mathrm{mRNA}$ present in infected cells by Northern blot analysis of poly(A)containing cytoplasmic RNA. Blots were probed with plasmid pLPS19A, containing an insert mapping within the open reading frame of the $65 \mathrm{~K}_{\mathrm{DBP}}$ gene. This probe detected only a single major mRNA species of approximately 1.8 kilobases in infected cells at all times examined (Fig. 5), in agreement with the previously reported size of the transcript of this gene (7). The $65 \mathrm{~K}_{\text {DBP }}$ mRNA was first detected at $4 \mathrm{~h}$ p.i. and appeared to accumulate through $6 \mathrm{~h}$ p.i., after which the level of mRNA was reduced.

We quantified the steady-state level of $65 \mathrm{~K}_{\mathrm{DBP}} \mathrm{mRNA}$ in infected cells at various times p.i. in the presence or absence of viral DNA synthesis (Fig. 6A). Maximum mRNA accumulation occurred at $6 \mathrm{~h}$ p.i. in the absence of PAA, but at 8 $h$ p.i. in the presence of the inhibitor. For direct comparison of this pattern with those produced by model $\beta$ and $\gamma$ genes, blots were stripped and reprobed with sequences specific for the gene encoding TK and, subsequently, with sequences specific for the gene encoding gC (Fig. 6B and $\mathrm{C}$, respectively). The 1.4-kilobase $t k$ transcript was present in maximum amounts at $6 \mathrm{~h}$ p.i. in the absence of PAA and displayed the same overall pattern of accumulation as the $65 \mathrm{~K}_{\mathrm{DBP}}$ gene transcript. The presence of PAA caused a superinduction of $t k \mathrm{mRNA}$, with maximum accumulation at $8 \mathrm{~h}$ p.i. In contrast, the steady-state level of the 2.7-kilobase $\mathrm{gC}$ transcript remained relatively high even at late times p.i., and very little of the transcript $(<3 \%$ of that observed in the absence of PAA) accumulated in the absence of viral DNA synthesis. The apparent drop in gC mRNA after $12 \mathrm{~h}$ p.i. reflects loss of cellular contents during centrifugation due to fragility of the cells at late times (results not shown). Nevertheless, gC mRNA content at $24 \mathrm{~h}$ p.i. remained at approximately $50 \%$ of the maximum level attained (at $12 \mathrm{~h}$ p.i.). Thus, the steady-state level of $65 \mathrm{~K}_{\mathrm{DBP}} \mathrm{mRNA}$, in the presence or absence of viral DNA synthesis, most closely resembles that of the model $\beta t k$ gene.

Rate of transcription of the $65 \mathrm{~K}_{\mathrm{DBP}}$ gene. The reduction in the rate of accumulation of $65 \mathrm{~K}_{\mathrm{DBP}} \mathrm{mRNA}$ after $6 \mathrm{~h}$ p.i. may have reflected several possibilities: (i) a complete block of $65 \mathrm{~K}_{\mathrm{DBP}}$ gene transcription following initiation of viral DNA synthesis; (ii) a decreased level of transcription following DNA synthesis; or (iii) a more rapid turnover of the transcribed mRNA at late times compared to early times. To ascertain whether or not transcription of the $65 \mathrm{~K}_{\mathrm{DBP}}$ gene occurs following the onset of viral DNA synthesis, nuclear run-on experiments were conducted. In these experiments the relative number of transcripts which have been initiated at a particular time after infection was determined by pulselabeling nuclear preparations with $\left[{ }^{32} \mathrm{P}\right]$ UTP. Under the conditions used, only elongation of previously initiated transcripts occurs (5). The amount of radioactivity in $65 \mathrm{~K}_{\mathrm{DBP}}$ gene-specific transcripts was assessed by hybridizing each labeled RNA sample to filters containing an excess of unlabeled pLPS19A plasmid DNA. As a control, samples were also hybridized to filters containing unlabeled plasmid vector pTZ19U. No transcripts specific for the $65 \mathrm{~K}_{\mathrm{DBP}}$ gene were detected above background until $4 \mathrm{~h}$ p.i. (Fig. 7). The level of $65 \mathrm{~K}_{\mathrm{DBP}}$ transcripts initiated increased through $8 \mathrm{~h}$ p.i. and declined thereafter. No hybridization to the $65 \mathrm{~K}_{\mathrm{DBP}}$ gene-containing insert was detected in samples from mockinfected cells harvested at $18 \mathrm{~h}$ post-mock-infection (results not shown).

To determine how the time of maximum rate of transcription correlated with the time of onset of viral DNA synthesis, the relative $65 \mathrm{~K}_{\mathrm{DBP}}$ gene copy number was determined at each time point by removing a portion of the nuclear preparation prior to the addition of labeled UTP. DNA was extracted, denatured, bound to nitrocellulose, and hybridized to ${ }^{32}$ P-labeled pLPS19A. The results (Fig. 7) indicate a significant increase in viral DNA template between 6 and $8 \mathrm{~h}$ p.i., with the maximum rate of viral DNA synthesis occurring between 8 and $12 \mathrm{~h}$ p.i. and corresponding to the onset of progeny DNA synthesis. Therefore, the time of maximum viral DNA synthesis corresponds to a drop in the rate of transcription of the $65 \mathrm{~K}_{\mathrm{DBP}}$ gene. However, significant initiation of transcription of the $65 \mathrm{~K}_{\mathrm{DBP}}$ gene does occur following the onset of viral DNA synthesis and continues through at least $18 \mathrm{~h}$ p.i. (Fig. 7). 

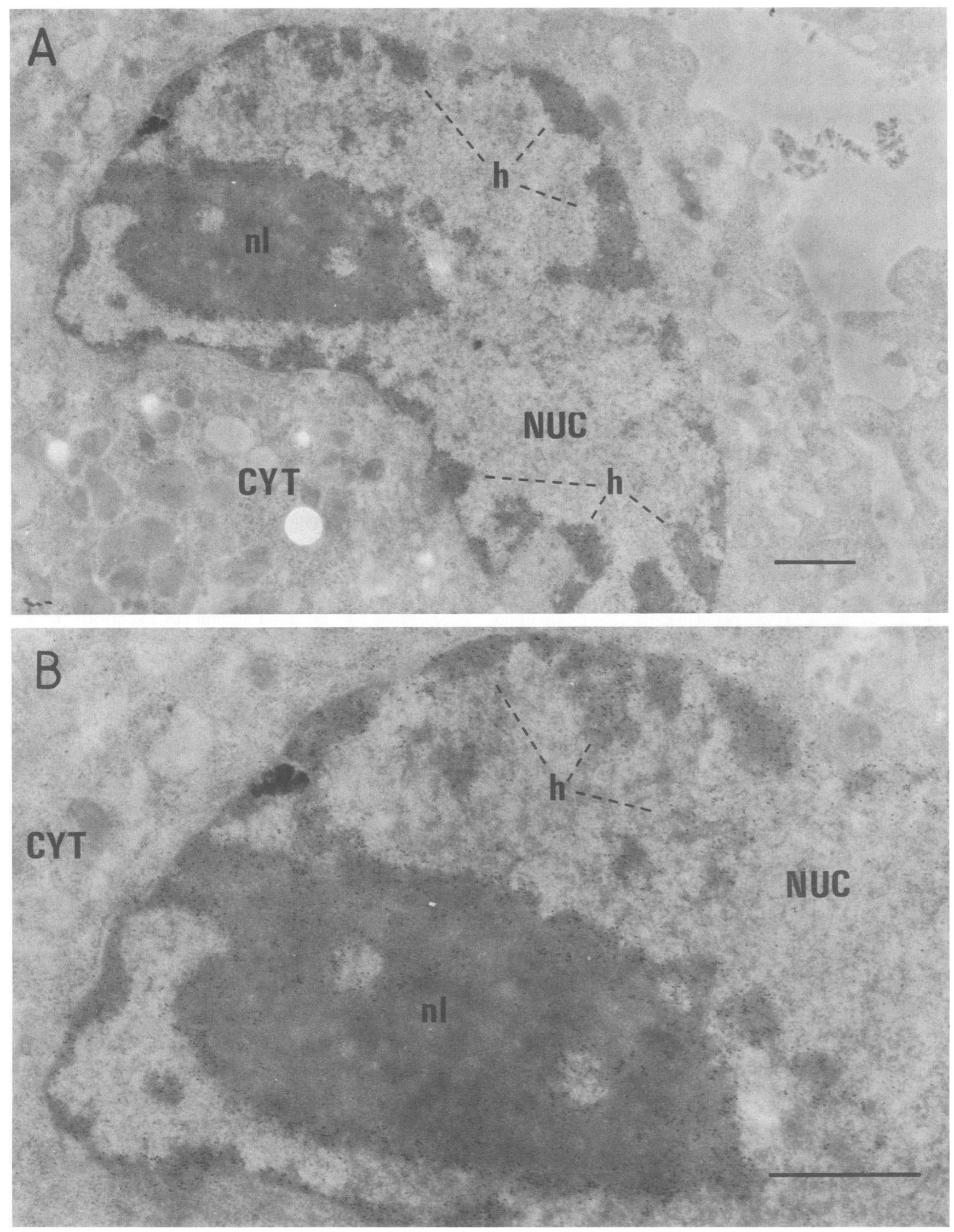

FIG. 2. Subcellular localization of $65 \mathrm{~K}_{\mathrm{DBP}}$. Electron micrographs of thin sections through $\mathrm{HSV}-1$-infected BHK cells harvested at $4 \mathrm{~h}$ (A and B) or $12 \mathrm{~h}$ (C and D) p.i. The sections were incubated with MAb 6898 diluted 1:500 in PBS-Tween 20. (B and D) Enlargements of areas of panels A and C, respectively. Bars, $1 \mu \mathrm{m}$. NUC, Nucleus; CYT, cytoplasm; NL, nucleolus; h, heterochromatin. 

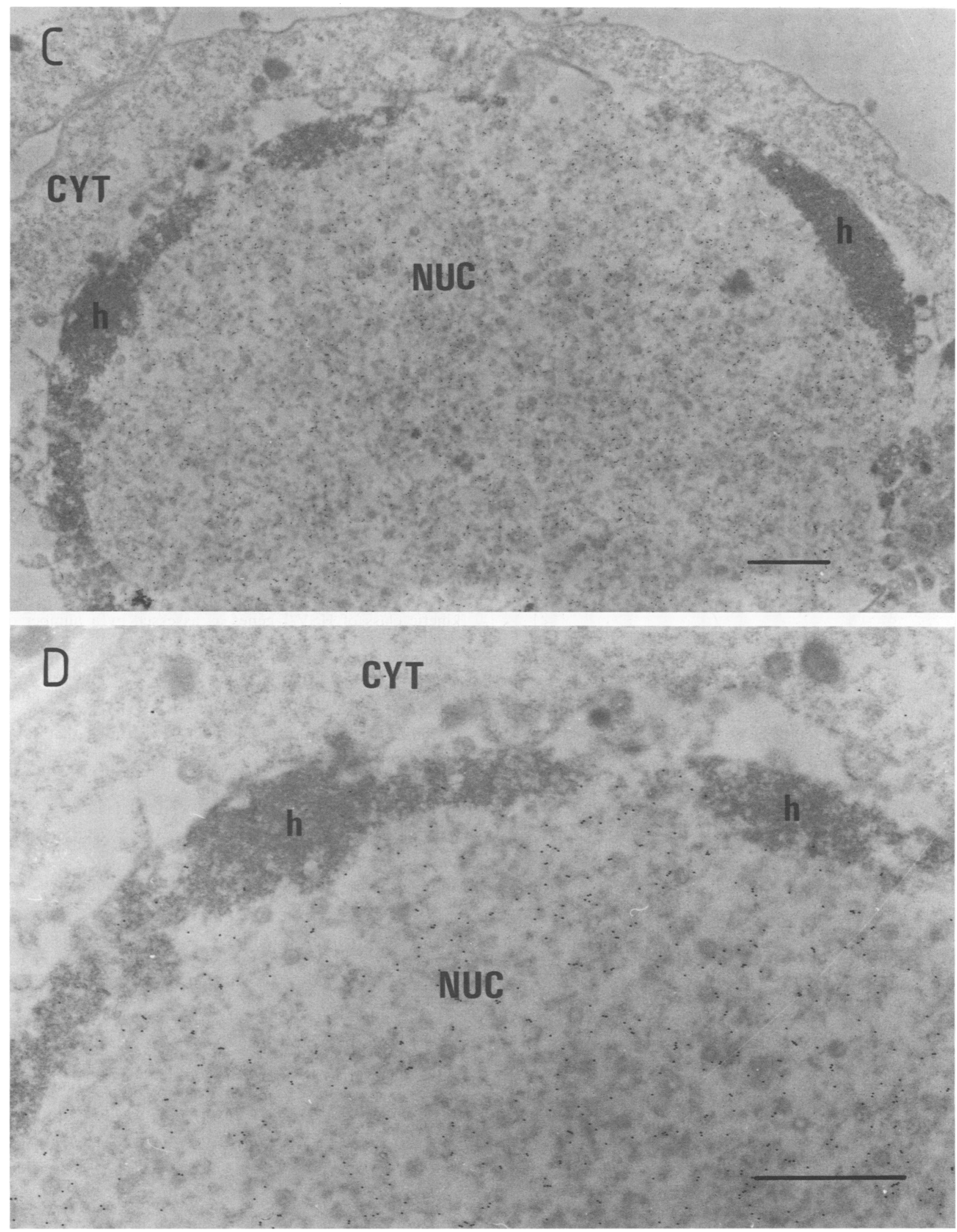

FIG. 2-Continued. 


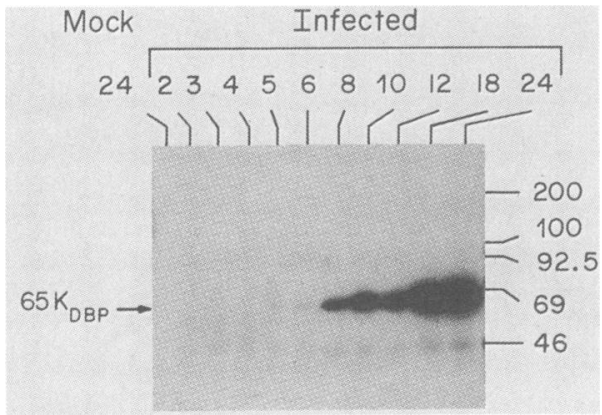

FIG. 3. Immunoblot of $65 \mathrm{~K}_{\mathrm{DBP}}$ present at various times p.i. Extracts of BHK cells mock-infected or infected with HSV-1 (KOS) and grown at $34^{\circ} \mathrm{C}$ for various amounts of time were electrophoresed on a denaturing $10 \%$ polyacrylamide gel and transferred to nitrocellulose. The blot was probed with MAb 6898 and ${ }^{125}$ I-protein A to detect the $65 \mathrm{~K}_{\mathrm{DBP}}$. The numbers above the lanes refer to the times (hours p.i.) at which the cells were harvested. The molecular sizes (in kilodaltons) of protein standards are indicated on the right.
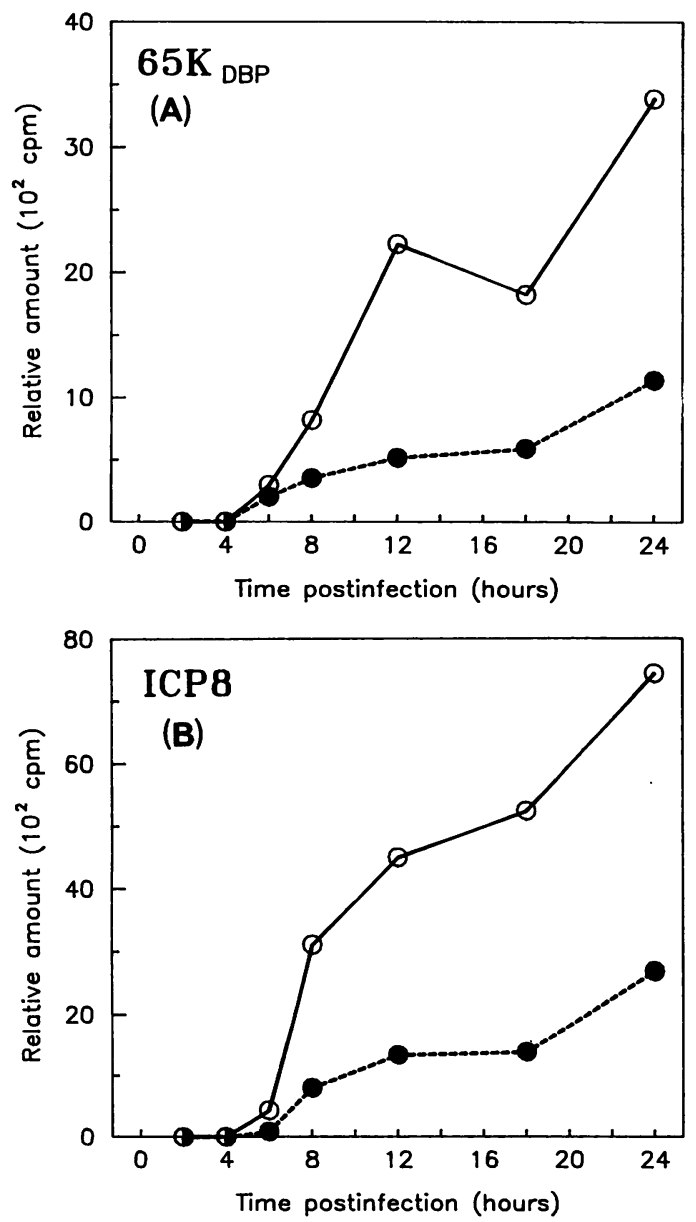

FIG. 4. Effect of PAA on accumulation of $65 \mathrm{~K}_{\mathrm{DBP}}$ and ICP8. BHK cells were infected with HSV-1 (KOS), grown at $34^{\circ} \mathrm{C}$ in the absence $(O)$ or presence $(O)$ of $400 \mu \mathrm{g}$ of PAA per $\mathrm{ml}$, and harvested at the indicated times, and extracts were prepared and spotted onto nitrocellulose. Blots were probed with MAb 6898 or 39S and subsequently with ${ }^{125} \mathrm{I}$-protein $A$ to detect $65 \mathrm{~K}_{\mathrm{DBP}}(\mathrm{A})$ or ICP8 (B), respectively. Radioactivity bound to the filters was quantified by liquid scintillation spectrometry.

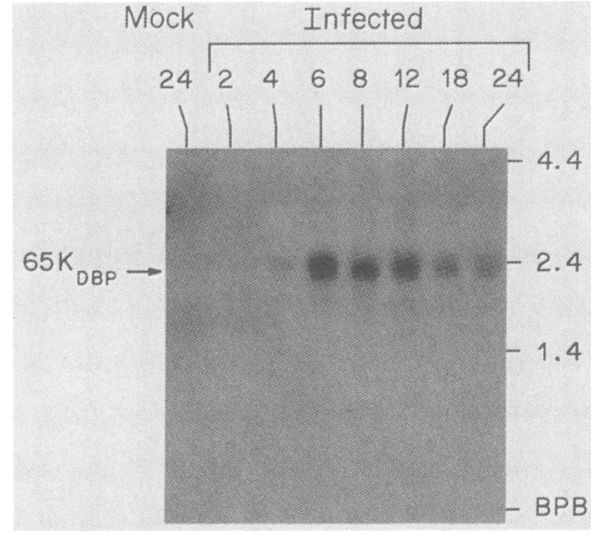

FIG. 5. Northern blot of $65 \mathrm{~K}_{\mathrm{DBP}}$ mRNA present at various times p.i. Total cytoplasmic RNA was extracted from BHK cells mockinfected or infected with HSV-1 (KOS) and grown at $34^{\circ} \mathrm{C}$ for various lengths of time. Poly(A)-containing species were then isolated by passage of the RNA over oligo(dT)-cellulose columns, denatured with glyoxal and dimethyl sulfoxide, and subjected to electrophoresis on a $1 \%$ agarose gel. RNA was transferred to Nytran, hybridized to nick-translated pLPS19A, washed, and exposed to X-ray film. The numbers above the lanes indicate the time p.i. (in hours) when samples were harvested, and the positions and sizes (in kilobases) of RNA standards are shown to the right. BPB indicates the location of the dye front.

\section{DISCUSSION}

The studies described in this report clearly demonstrate that the gene encoding $65 \mathrm{~K}_{\mathrm{DBP}}$ is a member of the early or $\beta$ kinetic class of HSV-1 genes as assessed by a number of parameters. Frink et al. (7) initially classified the transcript from this gene as a $\beta$ transcript on the basis of the presence of the transcript when DNA synthesis was inhibited with adenosine arabinoside. The pattern of protein accumulation that we found was consistent with the gene belonging either to the $\beta$ or $\beta \gamma$ class. In particular, we found that PAA dramatically reduced the amount of $65 \mathrm{~K}_{\mathrm{DBP}}$ detected by immunoblot at late times compared to that which was present in the absence of drug (Fig. 4A), a property expected of a late gene. However, cells also accumulated less ICP8, a $\beta$-gene product, in the presence of PAA (Fig. 4B). Therefore, we examined the steady-state levels of mRNA as well as the rate of initiation of transcription of the $65 \mathrm{~K}_{\mathrm{DBP}}$ gene to more accurately determine its kinetic class. The kinetics of accumulation of the $65 \mathrm{~K}_{\mathrm{DBP}}$ transcript was essentially the same in either the presence or absence of PAA and did not differ significantly from the pattern displayed by another $\beta$ gene, that encoding TK. Although PAA slightly reduced the level of $65 \mathrm{~K}_{\mathrm{DBP}}$ mRNA, significantly more of the $65 \mathrm{~K}_{\mathrm{DBP}}$ transcript was observed than of the $\mathrm{gC}$ transcript under the same inhibitory conditions. The low level of $65 \mathrm{~K}_{\mathrm{DBP}} \mathrm{de}-$ tected in the presence of PAA, despite the lack of significant inhibition of transcription, is not completely understood. We note, however, that there is a considerable lag in protein accumulation compared with mRNA accumulation even in the absence of drug. Moreover, between 18 and $24 \mathrm{~h}$ p.i. in the presence of PAA, the amount of $65 \mathrm{~K}_{\mathrm{DBP}}$ as well as ICP8 doubled, perhaps reflecting a protracted protein accumulation pattern.

It seems likely that the steady-state levels of $65 \mathrm{~K}_{\mathrm{DBP}}$ which we observed reflect the rate of initiation of transcription of the gene, in that both parameters achieved maximum levels between 6 and $8 \mathrm{~h}$ p.i. (Fig. 6 and 7). We have also 

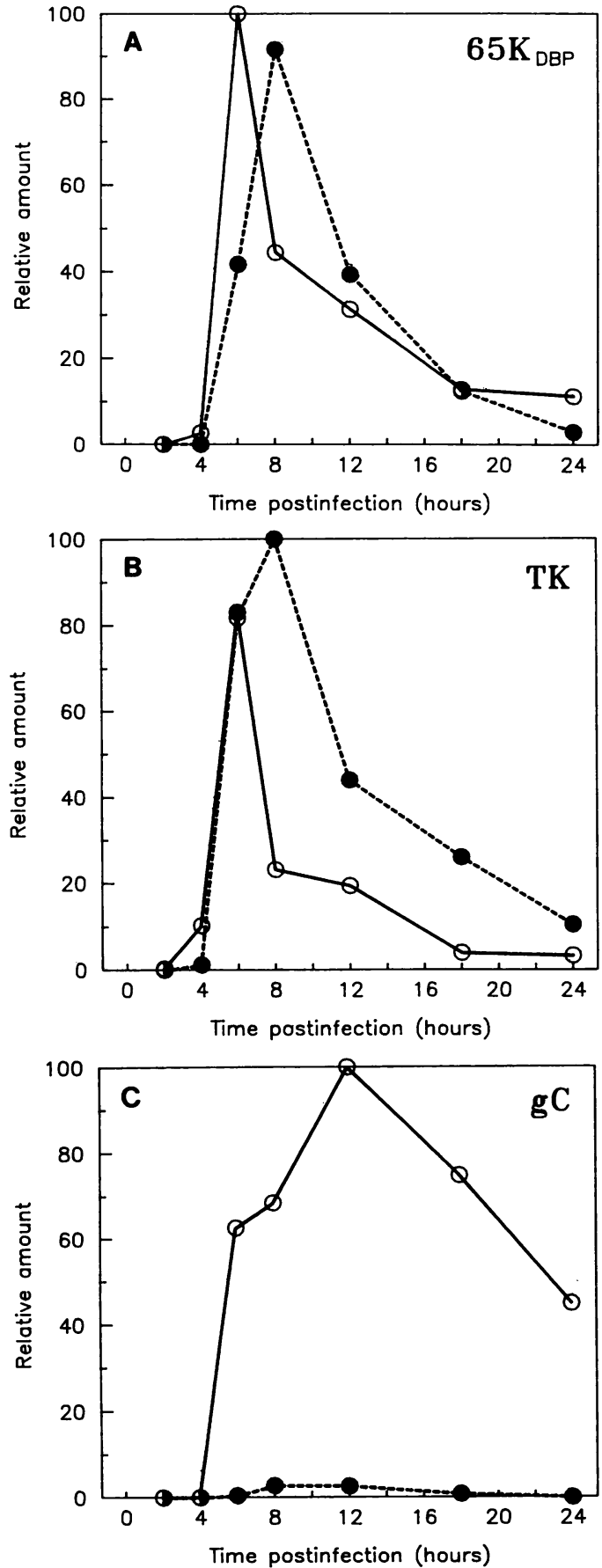

FIG. 6. Effect of PAA on steady-state levels of $65 \mathrm{~K}_{\mathrm{DBP}}, t k$, and gC mRNA. Northern blots of RNA from cells infected with HSV-1 (KOS) and grown at $34^{\circ} \mathrm{C}$ in the presence of $400 \mu \mathrm{g}$ of PAA per ml $(O)$ or in the absence of drug $(O)$ were prepared as described in the legend to Fig. 5 and were sequentially probed with pLPS19A, pTZTK3, and pgC-EX to detect $65 \mathrm{~K}_{\mathrm{DBP}}(\mathrm{A}), t k(\mathrm{~B})$, and $\mathrm{gC}(\mathrm{C})$ mRNA species, respectively. The blots were scanned with a densitometer, and the signals for each species were quantified as described in Materials and Methods. Values in the absence of drug represent the average of values obtained in two separate experiments.

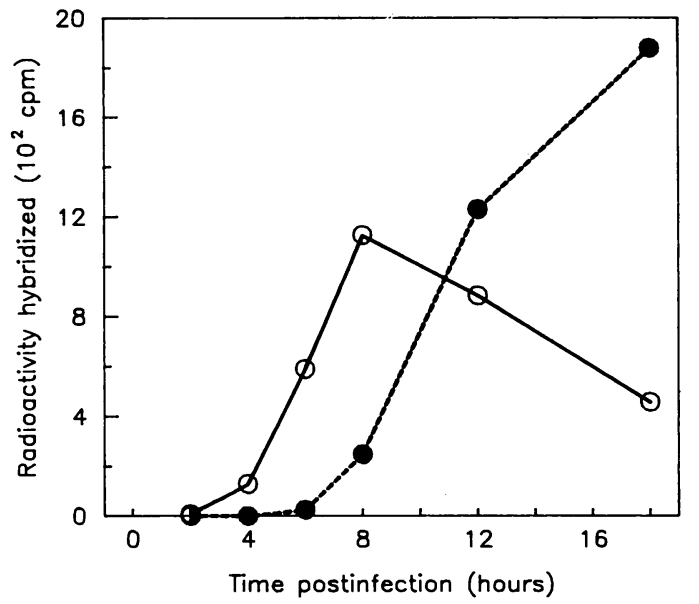

FIG. 7. Rate of initiation of $65 \mathrm{~K}_{\mathrm{DBP}}$ gene transcription. Nuclei were isolated from $\mathrm{BHK}$ cells which were mock-infected or infected with HSV-1 (KOS) for various amounts of time and pulse-labeled in vitro with $\left[{ }^{32} \mathrm{P}\right] \mathrm{UTP}$ in the presence of heparin and high salt. The resulting labeled RNA was hybridized to immobilized excess unlabeled $\mathrm{pLPS} 19 \mathrm{~A}$, containing a portion of the $65 \mathrm{~K}_{\mathrm{DBP}}$ open reading frame. The amount of radioactivity which hybridized to each filter was quantified by liquid scintillation spectrometry and is shown $(O)$ as the amount in excess over that which hybridized to filters containing the plasmid vector alone. DNA synthesis was monitored in the same samples by extracting total DNA from a portion of the nuclei that was removed before labeling the RNA as described in Materials and Methods and spotting it onto nitrocellulose. The relative number of $65 \mathrm{~K}_{\mathrm{DBP}}$ gene copies was determined by hybridization to a ${ }^{32} \mathrm{P}$-labeled pLPS19A probe $(\mathbf{O})$.

found no difference in the stability of $65 \mathrm{~K}_{\mathrm{DBP}}$ mRNA synthesized early compared with that synthesized late (unpublished results). Therefore, regulation of the $65 \mathrm{~K}_{\mathrm{DBP}}$ gene occurs at the level of transcriptional initiation. In fact, only one HSV-1 gene has been reported to have its regulation controlled posttranscriptionally, the $\beta \gamma$ gene encoding glycoprotein $\mathrm{D}(\mathrm{gD})(16)$. These investigators found that $\mathrm{gD}$ mRNA continued to accumulate in the cytoplasm of cells at late times postinfection, although synthesis of $\mathrm{gD}$ was minimal. A more recent report has found that rates of $\mathrm{gD}$ synthesis and the time at which the maximum rate is achieved are strain specific (37). Nevertheless, these investigators consistently observed a good correlation between the levels of $\mathrm{gD}$ RNA in the cytoplasm and the rate of $\mathrm{gD}$ synthesis.

Despite the lower transcription rate and low abundance of $65 \mathrm{~K}_{\mathrm{DBP}} \mathrm{mRNA}$ at late times postinfection, the protein product continues to accumulate, suggesting that the $65 \mathrm{~K}_{\mathrm{DBP}}$ may be a relatively stable protein. However, we have not directly examined the stability of the protein in pulse-chase experiments.

As expected for a protein involved in DNA synthesis, $65 \mathrm{~K}_{\mathrm{DBP}}$ was first detected by immunofluorescence at $3 \mathrm{~h}$ p.i. (the same time ICP8 was first detected), which precedes the onset of progeny DNA synthesis. Also as expected for a DNA-binding protein, $65 \mathrm{~K}_{\mathrm{DBP}}$ was localized in the nucleus of the infected cell. Immunofluorescence was clearly more sensitive in detecting the protein than immunoblotting since at an m.o.i. of 2.5 PFU/cell, positive fluorescence could be detected by $4 \mathrm{~h}$ p.i. (results not shown). We could not detect $65 \mathrm{~K}_{\mathrm{DBP}}$ by immunoblotting until $5 \mathrm{~h}$ p.i. even at an input m.o.i. of 10 PFU/cell (Fig. 3).

Initially, the protein accumulated rapidly in the nucleus 
and associated predominantly with the heterochromatin (Fig. 2A and B). However, at late times, the heaviest labeling was over the nucleoplasm and very little $65 \mathrm{~K}_{\mathrm{DBP}}$ was present in the heterochromatin (Fig. 2C and D). This agrees closely with the distribution observed by light microscopy. It has been shown by autoradiography that HSV DNA replication occurs in restricted areas within the nucleus (33, 34) that are similar to those occupied at equivalent times by the $65 \mathrm{~K}_{\mathrm{DBP}}$. A number of other HSV DNA-encoded proteins, including ICP8 and DNA polymerase, are known to exhibit similar localization patterns $(31,33)$. It is probable, therefore, that the temporal changes in the distribution of $65 \mathrm{~K}_{\mathrm{DBP}}$ largely reflect its role in viral DNA replication. In a separate report (L. D. Goodrich et al., manuscript in preparation), we will present evidence that the intranuclear localization of $65 \mathrm{~K}_{\mathrm{DBP}}$ does in fact reflect the state of viral DNA synthesis and that $65 \mathrm{~K}_{\mathrm{DBP}}$ colocalizes with ICP8 during productive replication to the same compartments in the nucleus.

\section{ACKNOWLEDGMENTS}

We thank Ann Cross and Martin Zweig for providing MAbs 6898 and 39S, respectively. We also thank Duncan McGeoch for providing sequence information prior to publication, George Milo for the use of the fluorescence microscope, Lee Johnson for the nuclear run-on protocol, and J. H. Subak-Sharpe for helpful discussions.

This work was supported in part by Public Health Service grant GM 34930 from the National Institutes of Health and grant no. MV-317 from the American Cancer Society to D.S.P., and by the Public Health Service Comprehensive Cancer Center Core grant CA 16958 from the National Cancer Institute.

\section{LITERATURE CITED}

1. Aviv, H., and P. Leder. 1972. Purification of biologically active globin messenger RNA by chromatography on oligothymidylic acid-cellulose. Proc. Natl. Acad. Sci. USA 69:1408-1412.

2. Bayliss, G. J., H. S. Marsden, and J. Hay. 1975. Herpes simplex virus proteins: DNA-binding proteins in infected cells and in the virus structure. Virology 68:124-134.

3. Brown, S. M., D. A. Ritchie, and J. H. Subak-Sharpe: 1973. Genetic studies with herpes simplex virus type 1 . The isolation of temperature-sensitive mutants, their arrangement into complementation groups, and recombination analysis leading to a linkage map. J. Gen. Virol. 18:329-346.

4. Conley, A. J., D. M. Knipe, P. C. Jones, and B. Roizman. 1981. Molecular genetics of herpes simplex virus. VII. Characterization of a temperature-sensitive mutant produced by in vitro mutagenesis and defective in DNA synthesis and accumulation of $\gamma$ polypeptides. J. Virol. 37:191-206.

5. Cox, R. F. 1976. Quantitation of elongating form A and B RNA polymerases in chick oviduct nuclei and effects of estradiol. Cell 7:455-465.

6. Frame, M. C., D. J. McGeoch, F. J. Rixon, A. C. Orr, and H. S. Marsden. 1986. The $10 \mathrm{~K}$ virion phosphoprotein encoded by gene US9 from herpes simplex virus type 1. Virology 150:321332 .

7. Frink, R. J., K. P. Anderson, and E. K. Wagner. 1981. Herpes simplex virus type 1 HindIII fragment $L$ encodes spliced and complementary mRNA species. J. Virol. 39:559-572.

8. Frink, R. J., R. Eisenberg, G. Cohen, and E. K. Wagner. 1983. Detailed analysis of the portion of the herpes simplex virus type 1 genome encoding glycoprotein C. J. Virol. 45:634-647.

9. Gallo, M. L., D. H. Jackwood, M. Murphy, H. S. Marsden, and D. S. Parris. 1988. Purification of the herpes simplex virus type 165 -kilodalton DNA-binding protein: properties of the protein and evidence of its association with the virus-encoded DNA polymerase. J. Virol. 62:2874-2883.

10. Godowski, P. J., and D. M. Knipe. 1983. Mutations in the major DNA-binding protein gene of herpes simplex virus type 1 result in increased levels of viral gene expression. J. Virol. 47:478-
486

11. Groudine, M., M. Peretz, and H. Weintraub. 1981. Transcriptional regulation of hemoglobin switching in chicken embryos. Mol. Cell. Biol. 1:281-288.

12. Holland, L. E., R. M. Sandri-Goldin, A. L. Goldin, J. C. Glorioso, and M. Levine. 1984. Transcriptional and genetic analyses of the herpes simplex virus type 1 genome: coordinates 0.29 to 0.45 . J. Virol. 49:947-959.

13. Honess, R. W., and B. Roizman. 1974. Regulation of herpesvirus macromolecular synthesis. I. Cascade regulation of the synthesis of three groups of viral proteins. J. Virol. 14:8-19.

14. Honess, R. W., and B. Roizman. 1975. Regulation of herpesvirus macromolecular synthesis: sequential transition of polypeptide synthesis requires functional viral polypeptides. Proc. Natl. Acad. Sci. USA 72:1276-1280.

15. Jofre, J. T., P. A. Schaffer, and D. S. Parris. 1977. Genetics of resistance to phosphonoacetic acid in strain KOS of herpes simplex virus type 1 . J. Virol. 23:833-836.

16. Johnson, D. C., and P. G. Spear. 1984. Evidence for translational regulation of herpes simplex virus type $1 \mathrm{gD}$ expression. J. Virol. 51:389-394.

17. Laemmli, U. K. 1970. Cleavage of structural proteins during the assembly of the head of bacteriophage T4. Nature (London) 227:680-685

18. Maniatis, T., E. F. Fritsch, and J. Sambrook. 1982. Molecular cloning: a laboratory manual. Cold Spring Harbor Laboratory, Cold Spring Harbor, N.Y.

19. Mao, J. C.-H., E. E. Robishaw, and L. R. Overby. 1975. Inhibition of DNA polymerase from herpes simplex virusinfected Wi-38 cells by phosphonoacetic acid. J. Virol. 15:12811283.

20. Marchetti, M. E., C. A. Smith, and P. A. Schaffer. 1988. A temperature-sensitive mutation in a herpes simplex virus type 1 gene required for viral DNA synthesis maps to coordinates 0.609 through 0.614 in $U_{L}$. J. Virol. 62:715-721.

21. Marsden, H. S., M. E. M. Campbell, L. Haarr, M. C. Frame, D. S. Parris, M. Murphy, R. G. Hope, M. T. Muller, and C. M. Preston. 1987. The $65,000-M_{\mathrm{r}}$ DNA-binding and virion transinducing proteins of herpes simplex virus type 1. J. Virol. 61: 2428-2437.

22. McGeoch, D. J., M. A. Dalrymple, A. J. Davison, A. Dolan, M. C. Frame, D. McNab, L. J. Perry, J. E. Scott, and P. Taylor. 1988. The complete DNA sequence of the long unique region in the genome of herpes simplex virus type 1. J. Gen. Virol. 69: 1531-1574

23. McGeoch, D. J., M. A. Dalrymple, A. Dolan, D. McNab, L. J. Perry, P. Taylor, and M. D. Challberg. 1988. Structures of herpes simplex virus type 1 genes required for replication of virus DNA. J. Virol. 62:444-453.

24. Overby, L. R., E. E. Robishaw, J. B. Schleicher, A. Rueter, N. L. Shipkowitz, and J. C.-H. Mao. 1974. Inhibition of herpes simplex virus replication by phosphonoacetic acid. Antimicrob. Agents Chemother. 6:360-365.

25. Parris, D. S., R. J. Courtney, and P. A. Schaffer. 1978. Temperature-sensitive mutants of herpes simplex virus type 1 defective in transcriptional and post-transcriptional functions required for viral DNA synthesis. Virology 90:177-186.

26. Parris, D. S., A. Cross, L. Haarr, A. Orr, M. C. Frame, M Murphy, D. J. McGeoch, and H. S. Marsden. 1988. Identification of the gene encoding the 65-kilodalton DNA-binding protein of herpes simplex virus type 1 . J. Virol. 62:818-825.

27. Peake, M. L., P. Nystrom, and L. I. Pizer. 1982. Herpesvirus glycoprotein synthesis and insertion into plasma membranes. J. Virol. 42:678-690.

28. Powell, K. L., and D. J. M. Purifoy. 1976. DNA-binding proteins of cells infected by herpes simplex virus type 1 and type 2 . Intervirology 7:225-239.

29. Preston, C. M. 1977. The cell-free synthesis of herpesvirusinduced polypeptides. Virology 78:349-353.

30. Purifoy, D. J. M., R. B. Lewis, and K. L. Powell. 1977. Identification of the herpes simplex virus DNA polymerase gene. Nature (London) 269:621-623.

31. Quinlan, M. P., L. B. Chen, and D. M. Knipe. 1984. The 
intranuclear location of a herpes simplex virus DNA-binding protein is determined by the status of viral DNA replication. Cell 36:857-868.

32. Rafield, L. F., and D. M. Knipe. 1984. Characterization of the major mRNAs transcribed from the genes for glycoprotein B and DNA-binding protein ICP8 of herpes simplex virus type 1 . J. Virol. 49:960-969.

33. Randall, R. E., and N. Dinwoodie. 1986. Intranuclear localization of herpes simplex virus immediate-early and delayed-early proteins: evidence that ICP 4 is associated with progeny virus DNA. J. Gen. Virol. 67:2163-2177.

34. Rixon, F. J., M. Atkinson, and J. Hay. 1983. Intranuclear distribution of herpes simplex virus type 2 DNA synthesis: examination by light and electron microscopy. J. Gen. Virol. 64: 2087-2092.

35. Sanders, P. G., N. M. Wilkie, and A. J. Davison. 1982. Thymidine kinase deletion mutants of herpes simplex virus type 1 . J. Gen. Virol. 63:277-295.

36. Showalter, S. D., M. Zweig, and B. Hampar. 1981. Monoclonal antibodies to herpes simplex virus type 1 proteins, including the immediate-early protein ICP4. Infect. Immun. 34:684-692.

37. Smith, I. L., and R. M. Sandri-Goldin. 1988. Evidence that transcriptional control is the major mechanism of regulation for the glycoprotein $\mathrm{D}$ gene in herpes simplex virus type 1-infected cells. J. Virol. 62:1474-1477.
38. Smith, K. O. 1964. Relationships between the envelope and the infectivity of herpes simplex virus. Proc. Soc. Exp. Biol. Med. 115:814-816.

39. Sureau, C., J.-L. Romet-Lemonne, J. I. Mullins, and M. Essex. 1986. Production of hepatitis B virus by a differentiated human hepatoma cell line after transfection with cloned circular HBV DNA. Cell 47:37-47.

40. Thomas, P. S. 1980 . Hybridization of denatured RNA and small DNA fragments transferred to nitrocellulose. Proc. Natl. Acad. Sci. USA 77:5201-5205.

41. Towbin, H., T. Staehelin, and J. Gordon. 1979. Electrophoretic transfer of proteins from polyacrylamide gels to nitrocellulose sheets: procedure and some applications. Proc. Natl. Acad. Sci. USA 76:4350-4354.

42. Vaughan, P. J., L. M. Banks, D. J. M. Purifoy, and K. L. Powell. 1984. Interactions between herpes simplex virus DNA-binding proteins. J. Gen. Virol. 65:2033-2041.

43. Weller, S. K., K. J. Lee, D. J. Sabourin, and P. A. Schaffer. 1983. Genetic analysis of temperature-sensitive mutants which define the gene for the major herpes simplex virus type 1 DNA-binding protein. J. Virol. 45:354-366.

44. Wu, C. A., N. J. Nelson, D. J. McGeoch, and M. D. Challberg. 1988. Identification of herpes simplex virus type 1 genes required for origin-dependent DNA synthesis. J. Virol. 62:435443. 